\title{
POSISI ILMU KEDOKTERAN DAN ILMU USHULUDDIN DALAM ILMU ISLAM
}

\section{Oleh : Danusiri}

\section{Abstract}

As a lecturer, my job is to teach and to administer course of Islamic philosophy. However, the dynamics of the profession had once required me to serve as a lecturer in public colleges. In this institution, I teach Islamic subjects that are integrated with core content of every study program such as midwifery, nursing, nutrition, health analysts, public health, mathematics, statistics, and medicine. Through deep reflection I discovered the concept of 'basic philosophy of iqra', a term borrowed from Quraish Shihab, that derived from QS.Al-"Alaq :1-5.

The concept was implemented through the activities of reading both qur'anic verses (quraniyyab) and kauniyyab verses, as the interpretation of the phrase mâ khalaqa. The results of reading can be in the form of something, or a concept or variable(s). If there is a basic relationship between two or more things, between two or more concepts, between two or more variables, then the theory exists. A set of theories that is cognate in the sense of similarity within "the body of knowledge" will bear a science. In principle there is only one science and is derived from Allah in His capacity as al'Alîm and is taught to man,' allamal insanâna mâ lam ya'lam '. Furthermore, the science will develop in line with the human activities due to continued reading activities which can be sequenced further in the conceptualization, theorization, and saintification. Therefore the science is growing and growing into several branches and continues to cross the borders. At this level, the figure of a science is much more specific. Ushuluddin science seems to be unrelated to medical science, but they actually have the same root i.e., the genealogical structure, namely al' Alim. and its 
implication is that the dichotomy of religion versus general science is really just a myth.

Key words : reading, conceptualization, theorization, saintification, and one science (islamic of science).

\section{A. Pendahuluan}

Topik kertas kerja ini ditulis karena dua hal, pertama alasan subjektif dan kedua alasan objektif. Penulis memiliki bidang kerja teknis mengampu matakuliah filsafat Islam, akan tetapi, dalam menjalani profesi terjadi dinamika pengembangan karier. Selama delapan tahun, 2005-2013, saya mengampu studi Islam pada: prodi ilmu-ilmu kesehatan, seperti ilmu kedokteran, ilmu keperawatan, ilmu kebidanan, ilmu gizi, ilmu analais kesehatan, ilmu kesehatan masyarakat, dan ilmu teknologi pangan. Selain itu, saya masih ditugasi mengajar AI (agama Islam) pada prodi statistika, pendidikan matematika, akutansi, managemen, kedokteran gigi, atau singkatnya seluruh prodi yang ada di UNIMUS.

Ampuan saya yang masih serumpun dengan filsafat Islam hanya filsafat ilmu. Plavon matakuliah ini sangat minor, hanya 1 SKS pada prodi ilmu keperawatan. Itu saja hanya bagian dari Matakuliah Ilmu Keperawatan Dasar (IKD). keseluruhan tugas mengajar materi ajaran Islam harus inberen dengan core masingmasing prodi. Kemasan materi AI (agama Islam) pada fakultas atau prodi yang satu harus berbeda dari prodi yang lainnya. Di samping itu AI harus dibingkai dalam format, artinya the body of science-nya harus tampak jelas. Tidak ada kata lain kecuali harus menerima tugas itu karena saya memang bagian baru dari UNIMUS dengan terbayang betapa gelapnya belantara ilmu yang akan saya ambah itu.

Atas dasar profesi seperti ini membuat saya harus berpikir bagaimana secara asasi matakuliah yang saya ampu 
atau disiplin ilmu yang menjadi bidang tugas saya bukan merupakan ilmu yang terserak-serak (anorganis), melainkan harus menjadi bagian anatomis-fa'alis dari ilmu atau filsafat yang memayunginya. Hasil dari renungan ini saya temukan dalam istilah falsafat dasar iqra' dengan meminjam istilah Quraish Shihab yang selanjutnya dikembangkan dalam kerangka filsafat ilmu. Inilah yang dimaksud alasan objektif.

\section{B. Falsafah Dasar Iqta'(Quraish Shihab, 1992:167)}

Falsafah berasal dari bahasa Arab. Padanan dalam bahasa Indonesia diucapkan filsafat. Kata ini berasal dari bahasa Yunani philos yang berarti cinta dan sophos yang berarti kebijaksanaan (wisdom). Yang dimaksud kebijaksanaan di sini adalah kebenaran. Artinya, filsafat adalah cinta kebenaran. Orang yang cinta kebenaran disebut filosof. Ketika kata 'falsafah' dirangkai dengan kata 'dasar' dan menjadi ungkapan 'falsafah dasar', kebenaran yang dimaksudkan adalah kebenaran yang tidak perlu dibuktikan (untestable thruth, meminjam istilah Popper, 1972:273-290), artinya kebenatan 'iqra' - dan apapun yang tersurat dalam lafal-lafal dalam Alquran - berada di luar wilayah rasio manusia dan dipercayai atas dasar iman. Karena sudah demikian jelasnya (badibi jali), tidak bisa diingkari lagi seperti 'sebagian lebih kecil daripada keseluruhan'; permulaan segala sesuatu adalah Yang Ada (al-b\}aqqul awwa $>$ b) Yang sekaligus Esa (al-b\}aqqul wa> bicd), semua berasal dari Yang Esa (Harun, 1973:15,16) dan tidak mungkin dari kekosongan, dalam arti lepas dari kehendak Allah. Lawan dari kebenaran yang petlu diuji disebut testable thruth atau testability, yaitu kebenaran yang datang dari selain Allah, antara lain kebenaran ilmiah, perlu atau dapat diuji (Popper, 1983:11,139,174).

Alquran sebagai sesuatu yang benar bagi setiap orang Islam adalah sesuatu yang benar mutlak, tanpa tawar, taken for granted, dan tidak ada keraguan. Dengan demikian, kebenatan 
Alquaran tidak perlu diuji (untestable - Muslim A.Kadir, 2003 : 5,10). Karena kebenaran Alquran tidak perlu diuji, bahkan tidak dapat dibuktikan salah secara rasio, maka sikap setiap muslim terhadap Alquran adalah beriman kepadanya. Iman berbeda dari percaya. Kepercayaan tidak meniscayakan konsekuensi eskatologis seperti dosa, siksa kubur, siksa neraka, pahala, haudl, baitul makmur, mustawa, raf-taf, dan surga (aljannab). Iman mengandung hal itu semua. Orang tidak beriman sesuai ajaran Alquran akan mendapatkan siksa kubur, kesulitan di padang mahsyar, dan siksa akhirat. Di dunia, orang yang tidak beriman dikategorikan kafir (ateis). Dengan demikian yang dimaksud ungkapan 'falsafah dasar iqra' adalah setiap orang Islam mesti beriman secara penuh tanpa ada ruang sekecil apapun keraguan bahwa ia harus membaca, sebagai respon terhadap perintah membaca: 'iqra' (bacalah). Kebenaran perintah membaca didasarkan pada iman. Implikasi lebih lanjut, bagi yang mau membaca berarti beriman, dan bagi yang tidak membaca berarti tidak beriman, atau sekurang-kurangnya iman yang perlu dibubuhi tanda tanya. Secara tegas, Alquran menganalogikan orang yang tidak berilmu karena tidak mau melakukan tafaqqub (satu diantara denotasi qara'a itu bagaikan binatang ternak atau lebih hina lagi (QS. al-A'raf/7:179).

Buah orang yang mau membaca adalah memperoleh pengetahuan, betata pun ia merasa tidak mengetahui hasil bacaannya. Ketidaktahuannya itulah pengetahuannya untuk sementara dan memicu hastat untuk mengulangi lagi hingga ia merasa mengunduh hasil dalam membaca. Semakin banyak membaca, semakin banyak memperoleh pengetahuan. Orang yang memiliki pengetahuan banyak, di lingkungan masyarakatnya disebut sebagai 'alim. Semakin banyak dan mendalam ilmu seorang 'alim disebut 'allamah. Komunitas orang-orang 'alim disebut 'ulama'. Karena falsafah dasar dalam Islam adalah iqra' (bacalah), maka kebenaran asasi dalam Islam 
menghendaki bahwa setiap umat Islam seharusnya menjadi orang yang rajin membaca, harus menjadi orang 'alim, dan harus menjadi 'allamah. Mengaku dirinya sebagai seorang muslim, tetapi tidak atau malas membaca berarti mengingkari diri akan keislamannya, bahkan melecehkan harkat martabat dirinya sendiri.

Karakter iman sejati adalah rajin membaca. Kemunafikan atau kekufuran terjadi karena ketidakmauan membaca. Pernyataan ini semakin jelas karena wahyu pertama dalam Islam yang diturunkan oleh Allah adalah perintah membaca itu sendiri. Demikian Allah berfirman:

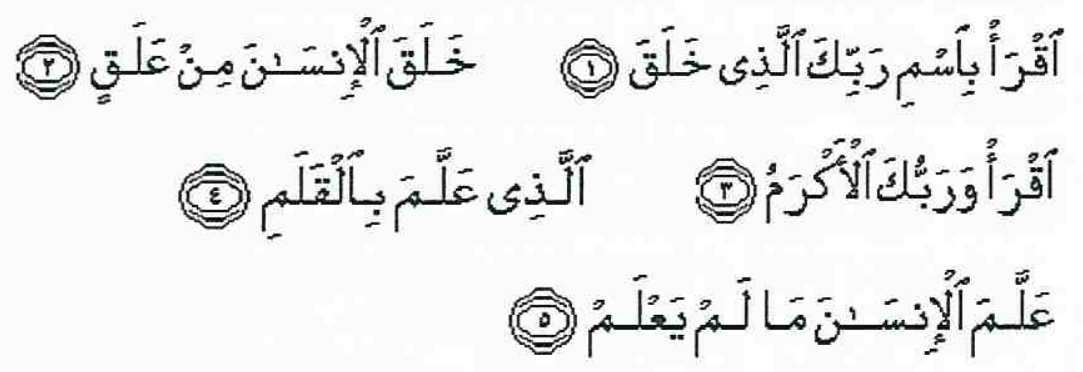

Artinya:

Bacalah dengan (menyebut nama Tuhanmu Yang Menciptakan. Dia telah menciptakan manusia dari segumpal darah. Bacalah, dan Tuhanmulah Yang Maha Pemurah. Yang mengajar manusia dengan perantaraan qalam. Dia mengajarkan kepada manusia apa yang tidak diketahuinya (Q.S. al'Alaq/96:1-5).

Dari ayat ini dapat dipahami bahwa starting point orang beragama dalam Islam secara legal bukan hanya syahadad, melainkan juga kesadaran dan komitmen mau dan rajin membaca (qara'a, iqra') sekaligus. Dengan demikian antara ktedo syahadad dan kesadaran membaca ibarat sekeping mata uang yang tampak dari dua sisi dan keduanya tidak mungkin dapat dipisahkan. Hanya syahadad saja tanpa kesediaan 
membaca berarti mengingkari Islam dan mengingkari dirinya sendiri, dan hanya membaca tanpa syahadad jelas-jelas ia kafir (ateis). Masuk Islam sejati secara resmi membaca syahadad sekaligus berkesadaran dan berkomitmen untuk mau dan rajin membaca.

1. Objek Bacaan

Berdasarkan wahyu pertama yang turun tersebut di atas yang harus dibaca adalah ma> khalaqa, yaitu sesuatu yang Allah telah ciptakan atau disebut juga makhluk (ciptaan). Ciptaan Allah ada dua macam: tertulis, yaitu kitab suci Alquran, dan yang tidak tertulis, yaitu alam semesta. seisinya, termasuk di dalamnya adalah hukum-hukum yang betlaku di dalamnya. Secara tradisional akademik objek bacaan tertulis disebut ayat qur'aniyyah dan objek bacaan yang tidak tertulis disebut ayat kauniyyab (Rahmat, 1988 : 19). Secara praktis ayat qur'aniyyah mengandung pengertian membaca setiap huruf, kata, dan kalimat yang termaktub dalam kitab suci al-Qur'ân al-Karim, dan membaca ayat kauniyyah adalah membaca setiap fenomena atau gejala alam semesta. Gejala mencakup benda, hal, dan peristiwa. Benda, hal, dan peristiwa disebut gejala karena keberadaannya selalu menggejala dalam ruang dan waktu.

Tercakup dalam pengertian membaca (qara'a, iqra', sebagai term mafbum/komrehensif) sebgaimana dijelaskan ayat-ayat qur'aniyyab yang turun sesudah ayat pertama itu, denotasinya (mâ shadaq) antara lain (terambil dari kata dasar):

a. Nadhara-yandhuru (dalam bahasa Indonesia menjadi nalar) yang secara praktis berarti meneliti secara cermat dan berulang-ulang sehingga dapat ditemukan hakikat pengertiannya dan kegunaannya dalam kehidupan, umpama: 


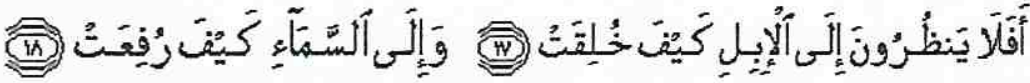

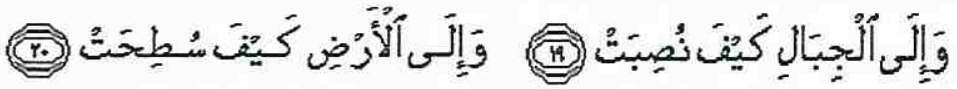

Artinya :

Maka apakah mereka tidak memperhatikan unta bagaimana dia diciptakan? Dan langit bagaimana ia ditinggikan? dan gunung-gunung bagaimana ia ditegakkan? dan bumi bagaiamana ia dihamparkan? (Q.S. al-Ghasyiyah/88: 17-20).

Ayat-ayat tersebut Secara eksplisit menjelaskan bahwa manusia supaya melakukan nadhar (menalar) terhadap unta, langit, gunung, dan bumi. Penunjukan objek-objek nadhar ini dapat dipahami sebagai contoh yang realisasinya adalah petunjuk untuk melakukan nadhar terhadap fenomena apa saja yang ada di alam semesta ini.

\section{b. Tafakkara-yatafakkaru}

Kegiatan berpikir mesti menghasilkan sesuatu pengertian, dan orang hanya bisa berpikir setelah ia memperoleh rangsangan baik dari luar melalui potensi indra maupun rangsangan dari dalam diri. Secara lugas dan terangterangan Allah memerintah hamba-hamba-Nya untuk melakukan kegiatan berpikir meningkatkan kualitas hidup supaya lebih baik dan selamat baik di dunia maupun di akhirat. Sekurang-kurangnya 18 kali Alquran ('Abd alBaqi, [t.th.]: 667) memerintahkan atau sekurangkurangnya himbauan supaya orang beriman melakukan kegiatan berpikir yang lafalnya menggunakan kata yang berakar dari kata fakkara,yafkaru, fikran. Contoh perintah ini adalah: 


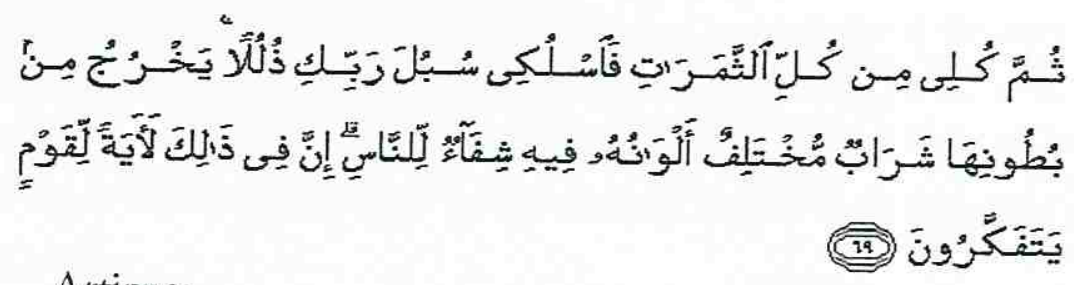

Artinya:

Kemudian makanlah dari tiap-tiap (macam) buah-buahan dan tempuhlah jalan Tuhanmu yang telah dimudahkan (bagimu). Dari perut lebah itu keluar minuman (madu) yang bermacam-macam warnanya. Di dalamnya terdapat obat yang menyembuhkan bagi manusia. Sesungguhnya, pada yang demikian itu benar-benar terdapat tanda (kekuasaan Tuhan) bagi orang-orang yang memikirkannya (Q.S. an-Nahl/16:69).

Ayat ini mengandung penjelasan bahwa sesuatu yang keluar dari perut lebah ternyata menjadi obat bagi manusia. Setelah dibuktikan melalui ilmu kedokteran, ilmu nutrisi, ilmu teknologi pangan, ilmu analis kesehatan sebagai objek material dan sebagai respon dalam bentuk memikirkannya ternyata benar adanya bahwa obat itu adalah madu dan berfungsi sebagai obat dari banyak macam penyakit (Lihat lampiran 1).

c. 'Aqala

Dari kata 'agala dapat diturunkan kata 'aqal, yang padanan kata dalam bahasa Indonesia adalah 'akal'. Secara praktis akal bisa dikatakan potensi yang aktualisasinya berpikir, mengingat, menghayal, dan yang sejenisnya. Tigapuluh satu kali ('Abd al-Baqi'[t.th.]:594-595) Alquran menyebut berbagai kata yang berakar dari kata 'aqala ('aqalu, ya'qilu, ta'qilu, ya'qilûn, ta'qilûn dan yang sejenisnya) yang jika dipahami mengandung petunjuk "siapa saja yang mau mengaktifkan akal untuk kepentingan dirinya akan 
membawa manfaat dan keselamatan, dan siapa yang tidak melakukannya atas peringatan itu akan berakibat celaka. Berikut ini contoh mengaktifkan akal terhadap peringatan Allah supaya memikitkan aneka macam tanaman yang kemudian menjadi rezeki:

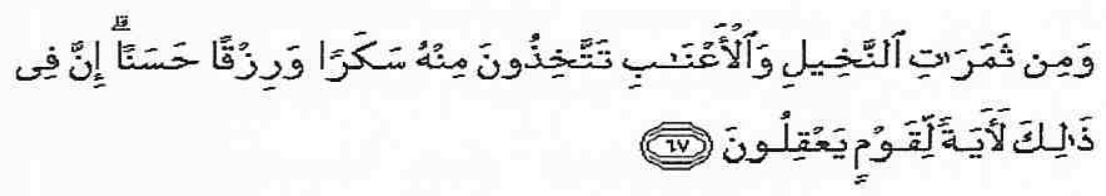

Artinya:

Dan dari buah kurma dan anggur, kamu buat minuman yang memabukkan dan rezeki yang baik, sesungguhnya pada yang demikian itu benar-benar terdapat tanda (kebenaran Allah) bagi orang yang memikirkan (Q.S. anNahk/16 : 67).

Berikut ini contoh orang yang tidak mau mengaktifkan akal untuk berpikir dan berakibat celaka di kemudiannya:

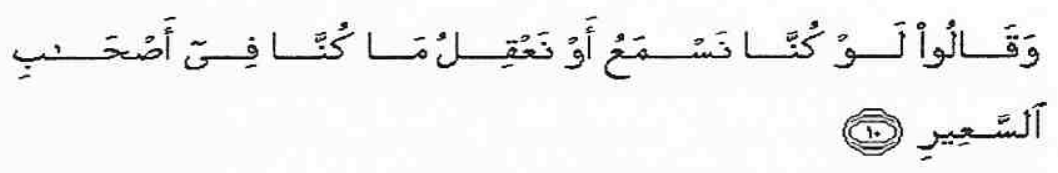

Artinya

Dan mereka berkata "sekiranya kami mendengarkan atau memikirkan (peringatan itu) niscaya tidaklah kami termasuk penghuni-penghuni neraka yang menyala-nyala (Q.S. al-Mulk/67: 10).

d. ¿ibrah (pelajaran)

Sembilan kali Allah memerintah kepada umat Islam supaya pandai-pandai mengambil pelajaran di balik berbagai peristiwa ('Abd al-Baqi,[t.th.] :565) umpama supaya mengambil pelajaran mengenai keberadaan 
binatang ternak. Dari situ justru kita minum air susunya. Allah berfirman:

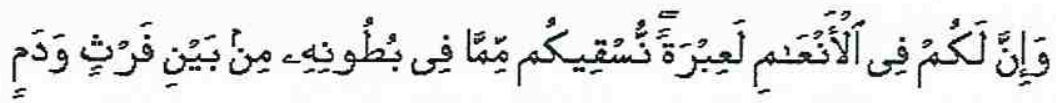

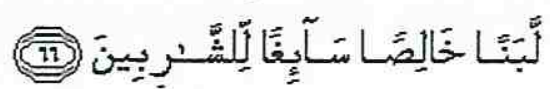

Artinya

Dan sesungguhnya pada binatang ternak terdapat pelajaran bagi kamu. Kami memeberimu minum dari pada apa yang berada dalam perutnya (berupa) susu yang bersih antara tahi dan darah, yang mudah ditelan bagi orang yang meminumnya (Q.S. an-Nahl/16: 66).

e. $R a^{\prime} a$ (melihat)

Pengertian ra'a secara praktis adalah melihat sesuatu fenomena, peristiwa atau hal disertai memikirkannya secara cermat, hati-hati, dan waspada. Berbagai kata jadian yang diturunkan dari kata ra'a, umpama yara, tara, nara, yaran, taran, naran, dan masih banyak lagi disebut dalam Alquran sebanyak 328 kali ('Abd al-Baqi, [t.th.]: 356-362), umumnya orang akan menyesal karena tidak mau melakukan perintah Allah untuk ra'a karena pasti berakibat fatal, contoh:

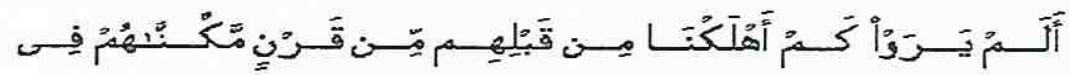

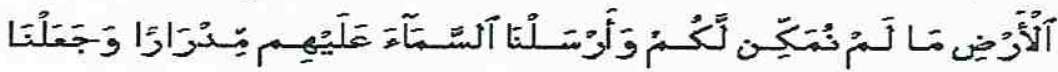

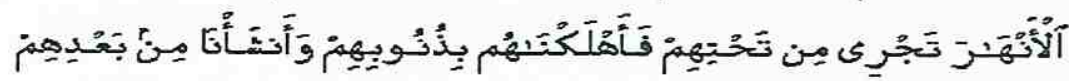
(3) قَرَّا

Artinya:

Apakah mereka tidak memperhatikan berapa banyaknya generasi-generasi yang telah kami binasakan sebelum mereka, padahal (generasi) itu telah Kami teguhkan 
kedudukan mereka di muka bumi, yaitu keteguhan yang belum pernah Kami berikan kepadamu, dan Kami curahkan hujan yang lebat atas mereka dan Kami jadikan sungai-sungai mengalir di bawah mereka, kemudian Kami binasakan mereka karena dosa mereka sendiri, dan Kami ciptakan sesudah mereka generasi yang lain (Q.S. alAn'am/6:6).

\section{f. Faqiba}

Kata yang dapat diturunkan dari kata faqiba antara lain yafqabu, tafqabu yang secara umum berarti memahami, paham, mengerti dan yang sejenisnya disebut dalam Alquran sebanyak 20 kali ('Abd al-Baqi'[t.th.]: 666-5557), yang menandakan bahwa umat Islam harus senantiasa memahami, mengerti diri dan lingkungan di mana ia berada, termasuk dari mana ia berasal dan akan ke mana ia pergi dari kehidupan ini kalau ia ingin hidup selamat. Ayat berikut memberikan penjelasan bagaimana manusia berada dalam keadaan hidup di dunia ini:

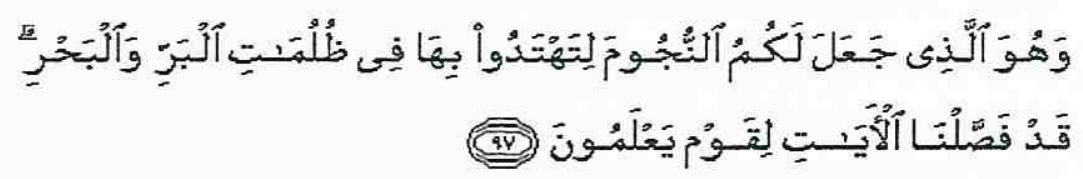

Artinya

Dan Dialah yang menciptakan kamu dari seorang diri, maka (bagimu) ada tempat tetap dan tempat simpanan. Sesungguhnya telah Kami jelaskan tanda-tanda kebesaran Kami kepada orang-orang yang mengetahui (Q.S. alAn'am/6:97).

\section{g. Fabima}

Satu kali Allah menyebut kata fabima dengan pengertian 'mengerti', yaitu pada: 


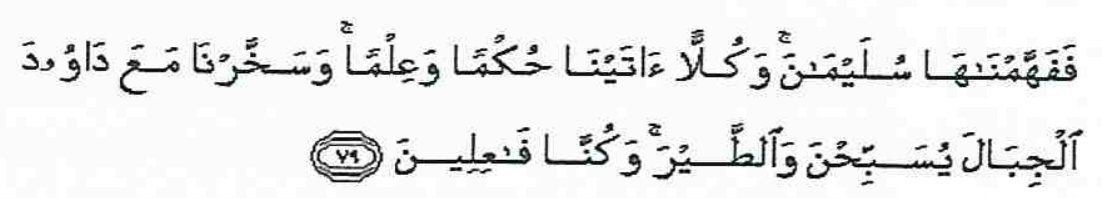

Artinya:

Maka Kami telah memberikan pengertian kepada Sulaiman tentang hukum (yang lebih tepat), dan kepada masing-masing mereka telah Kami berikan hikmah dan ilmu dan telah Kami tundukkan gunung-gunung dan burung-burung, semua bertasbih bersama Dawud. Dan Kamilah yang melakukannya (Q.S. al-Anbiya/21 : 79).

h. 'Alima

Dari kata 'alima dapat diturunkan antara lain kata al-ilm (ilmu). Berbagai turunan dari kata 'alima (ya'lamu, ta'lamu, na'lamu, ta'lamûn, ya'lamûn, i'lâmu, 'allama, dan yang sejenisnya) disebut sebanyak $749 \mathrm{kali}$ dalam Alquran yang secara keseluruhan berbicara soal pengetahuan atau ilmu, termasuk mengajar, mengajarkan, dan yang mengetahui atau berilmu ("Abd al-Baqi,[t.th.]:596-609). Contoh penggunaan kata 'alima dalam Alquran adalah sebagai berikut:
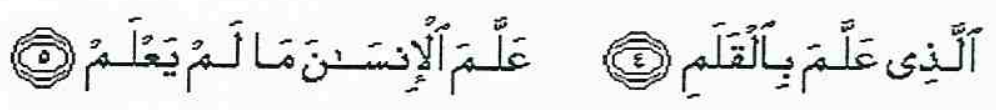

Artinya

Yang mengajar kepada (manusia) dengan perantaraan qalam. Yang mengajarkan manusia apa yang tidak diketahuinya (Q.S. al-'Alaq/96: 1-5).

i. Ulul Albâb

Ulul Albâb berarti orang yang berakal. Alquran menyebut kata ini sebanyak 13 kali ('Abd al-Baqi,[t.th.]:126-127). Orang-orang yang mengindahkan petunjuk atau 
peringatan Allah disebut ulul albâb, sedang yang tidak mengacuhkannya disebut orang yang tidak berakal, meskipun memiliki rasio. Rasio berbeda dari akal. Rasio hanya bercirikan logis, sedang akal di samping logis juga mengandung keimanan. Ayat berikut menyebutkan bahwa hanya ulul albâb saja yang dapat mengambil pelajaran atas firman Allah. Orang kafir, betapapun jenius tetap tidak berakal (ulul albâb):

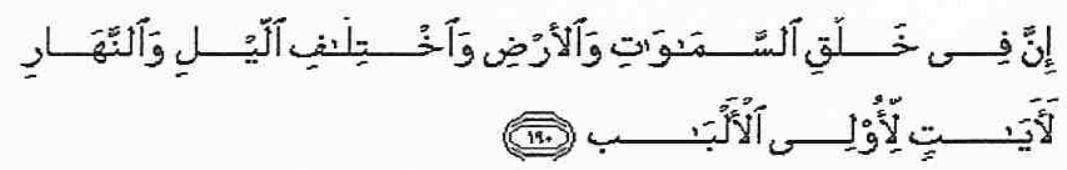

Artinya:

Sesungguhnya dalam penciptaan langit dan bumi, dan silih bergantinya malam dan siang terdapat tanda-tanda bagi yang orang-orang yang berakal (Q.S. Ali Imran/3: 190).

\section{j. Ulil Abshâr}

Empat kali kata ulil abshâr disebut dalam Alquran, yaitu: Ali Imran/13:13; an-Nur/24:44; Shad/38:45; dan alHasyr/59:2 dengan pengertian sama dengan pengertian ulul albâb. Hanya saja intensitas hasil pengetahuan yang didapat lebih mendalam, lebih luas, dan lebih komrehensif karena pengetahuan yang diperoleh juga bertolak dari eksperimen dan pengamatan yang berulangulang hingga menghasilkan pengetahuan yang amat meyakinkan atau mujarab. Arti kata mujarab secara literal adalah telah teruji. Setelah menjadi kata dalam bahasa menjadi mujarab mengandung arti dalam bahasa Jawa mandi, cespleng, dan thok cer. Demikian contoh pemakaian kata ulil abshâr dengan pengertian seperti yang dimaksud: 


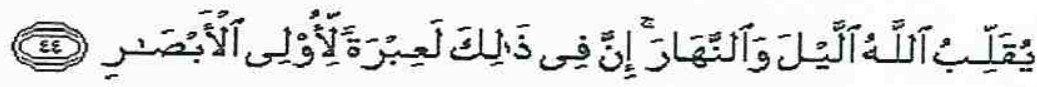

Artinya:

Allah mempergantikan malam dan siang. Sesungguhnya pada yang demikian itu, terdapat pelajaran yang besar bagi orang-orang yang mempunyai penglihatan (Q.S anNur/24:44).

\section{k. Ulin-Nuba}

Kata ini disebut dua kali, yaitu dalam surat Thaha/20:54 dan 128. Pengertiannya sinonim dengan ulil abshâr. Contohnya :

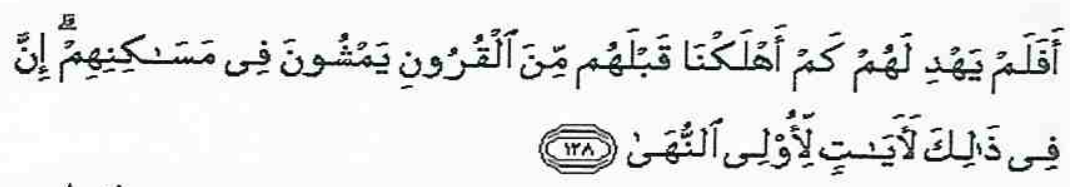

Artinya:

Maka tidakkah menjadi petunjuk bagi mereka (kaum musyrikin) berapa banyaknya Kami binasakan umat-umat sebelum mereka, padahal mereka berjalan (di bekasbekas) tempat tinggal umat-umat itu? Sesungguhnya pada yang demikian itu tertdapat tanda-tanda bagi orang yang berakal (Q.S. Thaha/20 : 148).

\section{1. al-Huda}

Pengertian al-buda secara literal adalah petunjuk. Berbagai turunan dari kata ini antara lain al-badi (orang yang memberi petunjuk), al-mubtadin (orang yang memperoleh petunjuk) dan al-mubtadîn adalah masih dalam kegiatan berpikir atau membaca (qara'a, iqra). Kata ini disebut dalam Alquran sebanyak 285 kali 9 (Abd al-Baqi, [t.th.]:900-905). Disebutkan antara lain bahwa orang yang 
tidak mau mengindahkan petunjuk Allah pastilah ia tersesat dan celaka, umpama firman berikut:

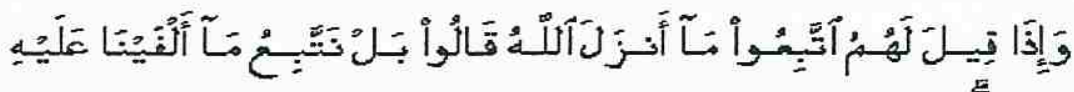

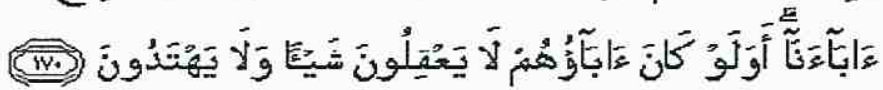

Artinya:

Dan apabila dikatakan kepada mereka: Ikutilah apa yang telah diturunkan Allah, mereka menjawab 'tidak', tetapi kami hanya mengikuti apa yang telah kami dapati dari (perbuatan) nenek moyang kami. (Apakah mereka akan mengikuti juga) walaupun nenek moyang mereka tidak mengetahui suatu apapun, dan tidak mendapat petunjuk? (Q.S. al-Baqarah/2: 170).

m. Tala

Pengertian tala bisa indentik dengan qara'a (membaca), mulai sekedar membaca huruf hingga mengerti pesanpesannya yang paling dalam (baqqa tilawâtib). Kata talan dan berbagai derivasinya terbut dalam Alquran cukub banyak, yaitu 62 kali (Abd al-Baqi, [t.th.]:197-198), menandakan betapa urgensinya bagi umat Islam untuk membaca.

Dari uraian ini dapat disimpulkan bahwa perintah membaca (igra) dalam permulaan wahyu kemudian diikuti dengan perintah-perintah lain yang masih dalam cakupan pengertian 'membaca', yaitu: fakara, 'aqala, 'ibrah, fabima, faqiba, alima, ulul albâb, ulil abshâr, ulinn-nuba, al'ibrah, tala, dan al-buda. Pergeseran penggunaan lafal qara'a kepada yang lain seperti fabima karena faktor koherensi dengan konteks, objek, manfaat, prosedur, atau akibat yang dibaca. Harap segera disadari bahwa keseluruhan perintah membaca (iqra'/qara'a) bettujuan agat setiap 
hamba Allah yang mengindahkan perintah itu menjadi orang yang selamat, pintar, dan bahagia, baik secara individu maupun kelompok, di dunia maupun di akhirat.

Hanya saja perlu disayangkan, bangsa Indonesia yang mayoritas penduduknya beragama Islam dan merupakan penduduk terbesar dunia, umat Islamnya yang diperintah Tuhannya untuk banyak membaca dan perintah membaca itu diulang-ulang lebih dari 1000 kali, justru menjadi umat yang secara umum bodoh, terbelakang, dan memiliki predikat yang sama sekali tidak diharapkan, yaitu korup dan bermental jelek (Krarr, 1988:89). Menyitir ungkapan Muhammad Abduh, Syaikh al-Azhar di Kairo Mesir ketika ia berkunjung dan menetap beberapa lama di Perancis mengatakan "Di sini hanya ada muslim tetapi tidak ada Islam. Di Barat hanya ada Islam tetapi tidak ada muslim."Sitiran ini agaknya berlaku di Indonesia hingga saat ini.

Mengaku masuk ke dalam Islam, tetapi langkah kakinya justru menuju keluar Islam. Falsafah dasar iqra' yang mestinya diambah, tetapi malah menapaki ruas-ruas jalan non iqra'. Jadilah ia tersesat amat jauh dari jalan Islam, terbelakang, tidak sejajar dengan bangsa-bangsa lain di dunia dalam ilmu pengetahuan dan teknologi (sebagai hasil kegiatan iqra). Membelokkan arah langkah kaki menuju jalan yang ditunjukkan Allah, yaitu membaca, memikirkan, meneliti, berekperimentasi, investigasi, menalar, mengambil pelajaran, mengamati, memahami, berusaha mengerti yang kesemuanya ditujukan untuk memperoleh kepintaran, kebijaksanaan, menguasai dan mengembangkan ilmu dan teknologi untuk kejayaan bukan hanya Islam dan muslimin, melainkan umat manusia secara keseluruhan, bukan hanya di dunia, melainkan juga di akhirat. 


\section{Prosedur Pembacaan}

Berdasarkan wahyu yang pertama turun, di dalam membaca baik ayat-ayat quraniyyah maupun ayat-ayat kauniyyah harus disadari semata-mata melaksanakan perintah Allah. Pekerjaan membaca (qara'a) dan pelaksanaannya qara'a adalah atas nama Allah (bismi rabbika). Implikasi yang diperoleh dari pemahaman ini menuntun kepada sikap mental, betapapun seseorang itu luar biasa pintar, cerdas, dan jenius akan tetap tawad \} $\hat{u}^{\prime}$ dan merendah diri di hadapan Allah karena apapun yang dilakukan dalam kegiatan membaca adalah atas nama Allah, bukan atas nama dirinya sendiri. Selain itu juga berimplikasi bahwa kegiatan membaca karena dikerjakan atas nama Allah akan terhitung sebagai ibadah dan perbuatan suci. Dari sini dapat diturunkan premis minor bahwa "Belajar adalah kegiatan suci dan ibadah, kuliah dalam kelas adalah kegiatan suci dan ibadah, eksperimentasi di laboratorium adalah kegiatan suci dan ibadah, dan mengambil hikmah di balik setiap peristiwa adalah kegiatan suci dan ibadah manakala dimotivisikasi dan ditujukan semata-mata atas nama Allah.

3. Hasil Pembacaan dan Jangkauannya

Ketika umat Islam melakukan kegiatan membaca (inklusif berbagai pengertian yang terkandung di dalamnya: nalar, memperhatikan, bereksperimentasi, mengambil pelajaran, meneliti, mengingat, berimaginasi, berkonsentrasi, dan merenung, akan memperoleh sesuatu. Dalam dunia ilmu (science), 'sesuatu' itu disebut pengetahuan (knowledge). Dari sini dapat diturunkan sebuah teori, "Semakin banyak membaca, semakin banyak pula memperoleh pengetahuan". Jika secara logis atau empiris dua atau lebih 'sesuatu' yang juga dapat sebut dua atau lebih variabel ada hubungan dasar, yaitu hubungan yang mesti ada dan tidak boleh tidak ada, 
maka akan memunculkan 'sesuatu, pengetahuan, variabel baru sebagai kesenyawaan dua 'sesuatu' tadi yang disebut teori (Russel, 1979: 439, Van Laer, 1962:43).

Contoh hubungan dua 'sesuatu', disebut juga konsep, fakta atau variabel bertolak dari firman Allah berikut:

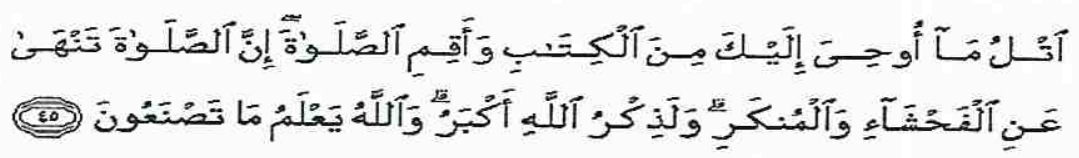

Artinya:

Bacalah apa yang telah diwahyukan kepadamu, yaitu al-Kitab (Alquran) dan dirikanlah shalat. Seșungguhnya shalat itu mencegah dari (perbuatan-perbuatan) keji dan mungkar. Dan sesungguhnya mengingat Allah (shalat) adalah lebih besar (keutamaannya daripada ibadah-ibadah yang lain). Dan Allah mengetahui apa yang kamu kerjakan (Q.S al'Angkabut/29:45).

Dari ayat ini dapat diambil (1) 'sesuatu', konsep, atau variabel 'shalat' (2) keji dan mungkar. Di sini ada hubungan antara shalat dan kekejian. Hubungan itu bercorak sebab akibat, tetapi bersifat peluang. Ada Orang melakukan salat justru berbuat keji dan mungkar, contohnya melakukan hubungan sek bebas dan korupsi. Ada orang melakukan salat lalu terjauh dari perbuatan keji dan mungkar, yaitu menjadi shalih. Dengan demikian hubungan antara konsep salat dan konsep keji-mungkar tergantung oleh faktor lain. Faktor ini disebut faktor pengantara. Faktor pengantara bisa berwujud sebagai faktor penentu, faktor penghambat atau faktor pendukung. Jika digambarkan akan diperoleh bagan sebagai berikut: 


\section{DIAGRAM I}

\begin{tabular}{|c|c|c|c|}
\hline $\begin{array}{l}\text { Unsur Dasar } \\
1 \text { kegiatan } \\
\text { salat }\end{array}$ & $\begin{array}{l}\text { Faktor penghambat: } \\
\text { Dilaksanakan di } \\
\text { sembarang tempat, } \\
\text { Sering telat, } \\
\text { Tidak berjamaah, } \\
\text { Pakaian kotor, } \\
\text { Bau badan tak } \\
\text { sedap, Sering } \\
\text { kosong, shalat tidak }\end{array}$ & $\begin{array}{l}\text { Unsur } \\
\text { Dasar 2: } \\
\text { syarat dan } \\
\text { rukun tidak } \\
\text { dipenuhi, } \\
\text { tidak } \\
\text { bhusyu' }\end{array}$ & $\begin{array}{l}\text { Kekejian } \\
\text { muncul:kolusi, } \\
\text { nepotisme } \\
\text { korupsi, } \\
\text { mabuk, zina, } \\
\text { nge-drugs, } \\
\text { Mencuri. } \\
\text { menipu, curang, } \\
\text { "' }\end{array}$ \\
\hline & $\begin{array}{l}\text { tahu arti bacaan } \\
\text { shalat, Tidak } \\
\text { tumukninah, dll } \\
\text { Hanya formalitas } \\
\text { dll }\end{array}$ & & $\begin{array}{l}\text { Predikat shalih } \\
\text { hilang }\end{array}$ \\
\hline
\end{tabular}

\section{DIAGRAM II}

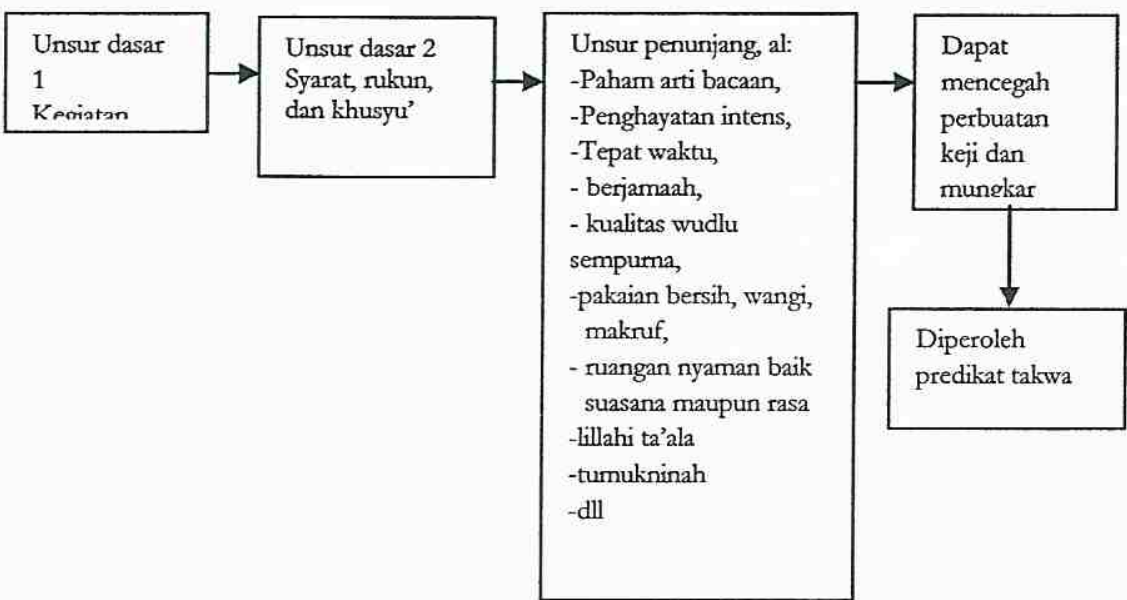

\section{Keterangan:}

1. Memakai wewangian, memenuhi sunnah-sunnah, di masjid, berjamaah adalah faktor pendukung yang posisinya sebagai unsur yang boleh ada dan boleh tidak.

2. Tuma'ninah, menghayati makna yang dibaca, khusyu' bisa disebut faktor penentu 
3. Tidak khusyu' adalah faktor penghambat bagi menghilangkan variabel keji dan mungkar.

Dari bagan-bagan ini dapat disusun teori: Jika melakukan salat dengan kualitas tuma'ninah, khusyu', dan menghayati makna bacaannya, maka berpeluang besar dapat mencegah perbuatan keji dan mungkar. Dalam teori ini sesuatu atau variabel yang mesti ada adalah (1) kegiatan salat, dan (2) kualitas tuma'ninah, khusyu', dan penghayatan bacaanya. Selanjutnya juga dirumuskan teori antitesisnya "jika melakukan salat dengan kualitas tidak khusyu', hanya formalitas, pasti tidak bisa meninggalkan perbuatan keji dan mungkar". Unsur teori ini adalah (I) kegiatan salat, dan (2) tidak ada kualitas: khusyu', tuma'ninah, dan penghayatan makna salat.

Jika ada hubungan sistematis (logis, empiris) antar berbagai teori (Kemeny, 1981: 175), maka akan muncul sesuatu. Sesuatu itu disebut ilmu. Dalam ungkapan sejenis disebutkan apabila kumpulan konsep, batasan, proposisi, teori diorganisasikan secara tepat maka akan menghasilkan sesuatu yang disebut ilmu (Goode\&Haft, 1998:34). Dengan demikian dapat dibuat bagan unsur-unsur pembentuk ilmu sebagai berikut:

B A GAN IL M U

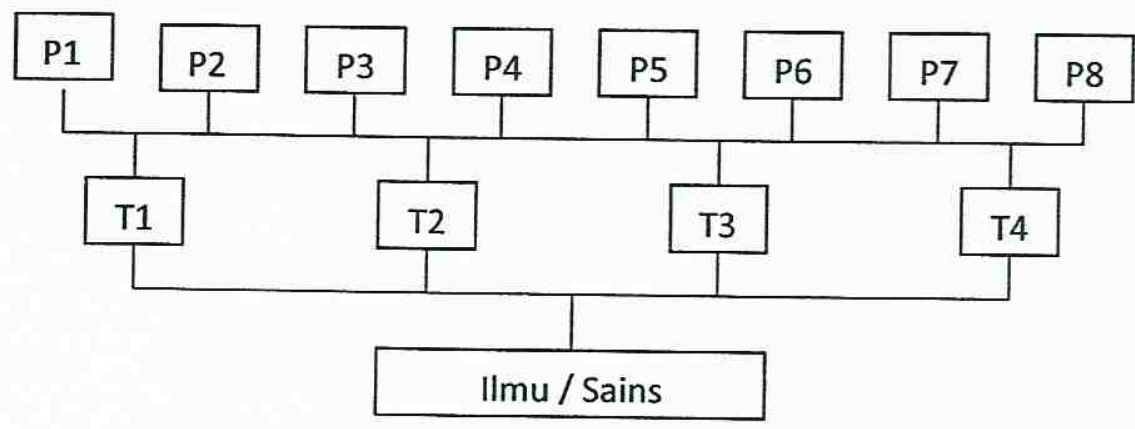




\section{Keterangan:}

P = bisa berwujud sesuatu, pengetahuan, konsep, atau variabel

$\mathrm{T}=$ teori

Di muka dijelaskan bahwa yang harus dibaca orang Islam adalah ayat quraniyyah dan ayat kauniyyah. Dari sini segera dapat dipahami bahwa membaca ayat yang pertama akan memeperoleh konsep, pengetahuan, variabel, batasan, proposisi kemudian setelah disistematissasi sedemikian rupa mengerucut menjadi sejumlah teori, dan selanjutnya meruncing menjadi sebuah ilmu. Jika kegiatan membaca diteruskan secara berkesinambungan dengan objek-objek forma tertentu, maka akan menghasilkan sejumlah ilmu seperti ilmu fiqh, ilmu kalam, ilmu bahasa (nahwu, sharaf, dan balaghah), hadis ('ulûm al-hadìs dan tafsir-tafsir/syarah hadisnya), tafsir ('ulûm at-tafsîr dan aneka macam corak tafsir Alquran), dan ilmu Ushuluddin. Dari ayat kauniyyah akan diperoleh konsep, variabel, batasan, proposisi, teori, dan ilmu perilaku, seperti: ilmu akhlaq, ilmu pendidikan Islam (ilmu tarbiyah dan ilmu dakwah (dalam bentuknya yang mutakhir), Sementara itu pembacaan terhadap ayat kauniyyab yang objeknya fakta-fakta alami akan memperoleh konsep, batasan, proposisi, teori, dan ilmu tentang alam (ilmu-ilmu kealaman atau natural sciencies). Akhirnya, setelah didapati ilmu-ilmu yang selama ini disebut ilmu-ilmu agama atau keagamaan juga kita mendapat ilmu-ilmu yang selama ini disebut ilmu kealaman atau umum dapat disistemisasi kerangka epistemologi (cabang filsafat yang membahas tentang pengetahuan yang meliputi: asal-usul, cara memperolehnya, struktur, hakikat, dan validitasnya, (De Runes, 1976:93-95) sebagai berikut: 
a. Sumber ilmu adalah Alquran dan alam semesta yang keduanya bersumber dari Allah (al-Alîm, al-Mu'allim alAwñẩ).

b. Cara memperoleh ilmu berawal dari kegiatan membaca (iqra') dengan mengaktualisasikan potensi intuisi, rasio, indra secara terpadu atau berjenjang tergantung pada objek yang sedang dibaca apakah objek qur'aniyyah atau sesuatu dari ketakterhinggaan objek kauniyyah.

c. Hasil yang diperoleh adalah konsep, teori, ilmu: al-ilm al-quraniyyah, dan al-ilm alkauniyyah. Al-ilm al-qur'aniyyah beranak-pinak sehingga melahirkan ilmu tafsir, ilmu hadis, ilmu kalam, ilmu fiqih, ilmu tarbiyyah, ilmu syariah, dan ilmu ushuluddin. Masing-masing ilmu tersebut masih bisa dikembangkan dan memungkinkan lahir ilmu-ilmu baru yang lebih spesifik. al-Tlm alkauniyyah juga beranak-pinak sehingga melahirkan: ilmuilmu sosial dan ilmu-ilmu teknis-praktis. Dalam tradisi Barat, yang disebut al-ilm al-kauniyyah secara prinsip bertolak dari dua macam pengetahuan, yaitu tentang fakta-fakta dan pengetahuan tentang hubungan diantara fakta (Russel, 1979:439). Dalam kesempatan lain Russel mengatakan: Science, ever since the time of the Arabs, has had two functions: (1) to enable us to know things, and (2) to enable us to do things (Russel, 1985:29).

Hasil jadi dari kedua jenis pengetahuan ada yang menyebutnya bahwa struktur ilmu meliputi: bumanioral sciencies, social sciencies, dan natural sciencies, sebagaimana yang dianut secara resmi oleh otoritas legal intelektualisme Indonesia yang mewujud dalam konsursium ilmu. Versi lain menyebutkan normative sciencies, speculative sciencies atau teoritical sciencies, dan 
practical sciencies (Muslim Kadir, 2003:194; Van Laer, I: 17).

d. Hakikat ilmu adalah ilmu Allah, dalam kapasitasnya sebagai al-Alim. dengan penjelasan lebih lanjut bahwa ilmu milik manusia, bahkan nyawanya hanya sekedar 'titipan'Allah.

e. Kebenaran atau validitas ilmu dengan cara diukur dari keseuaian jenis ilmu. Dengan demikian ada kebenaran empiris, kebenaran logis (rasionalis), kebenaran intuitif, dan kebenaran etis, yaitu kebenaran atas dasar iman. Masing-masing kebenaran itu tidak saling menegasikan, melainkan saling melengkapi dan berpuncak pada kebenaran yang bersifat ilahiyah, atau disebutnya kebenaran multi faset meliputi kebenaran: indrawi, rasional, pengalaman sufi, dan berpuncak pada kebenaran transenden (Noeng Muhadjir, 1992:90-100).

f. Manfaat ilmu adalah kualitas hidup yang baik secara lahiriah, yaitu hidup yang secara material betkecukupan, bermartabat, dan terhormat, yang secara singkat memperoleh kelapangan rezeki. Atribut ini semata-mata untuk beribadah kepada Allah yang hasilnya lebih lanjut mewrujud dalam bentuk kualitas hidup (shalibûn, muttaqûn, mub\}sinûn). dan akibat lebih lanjut adalah sa'adah fid-daraini (kebahagiaan hidup dunia-akhirat).

Jika dibuat bagan tentang epistemologi ilmu Islam akan diperoleh bagan sebagai berikut: 


\section{BAGAN EPISTEMOLOGIS ILMU ISLAM}

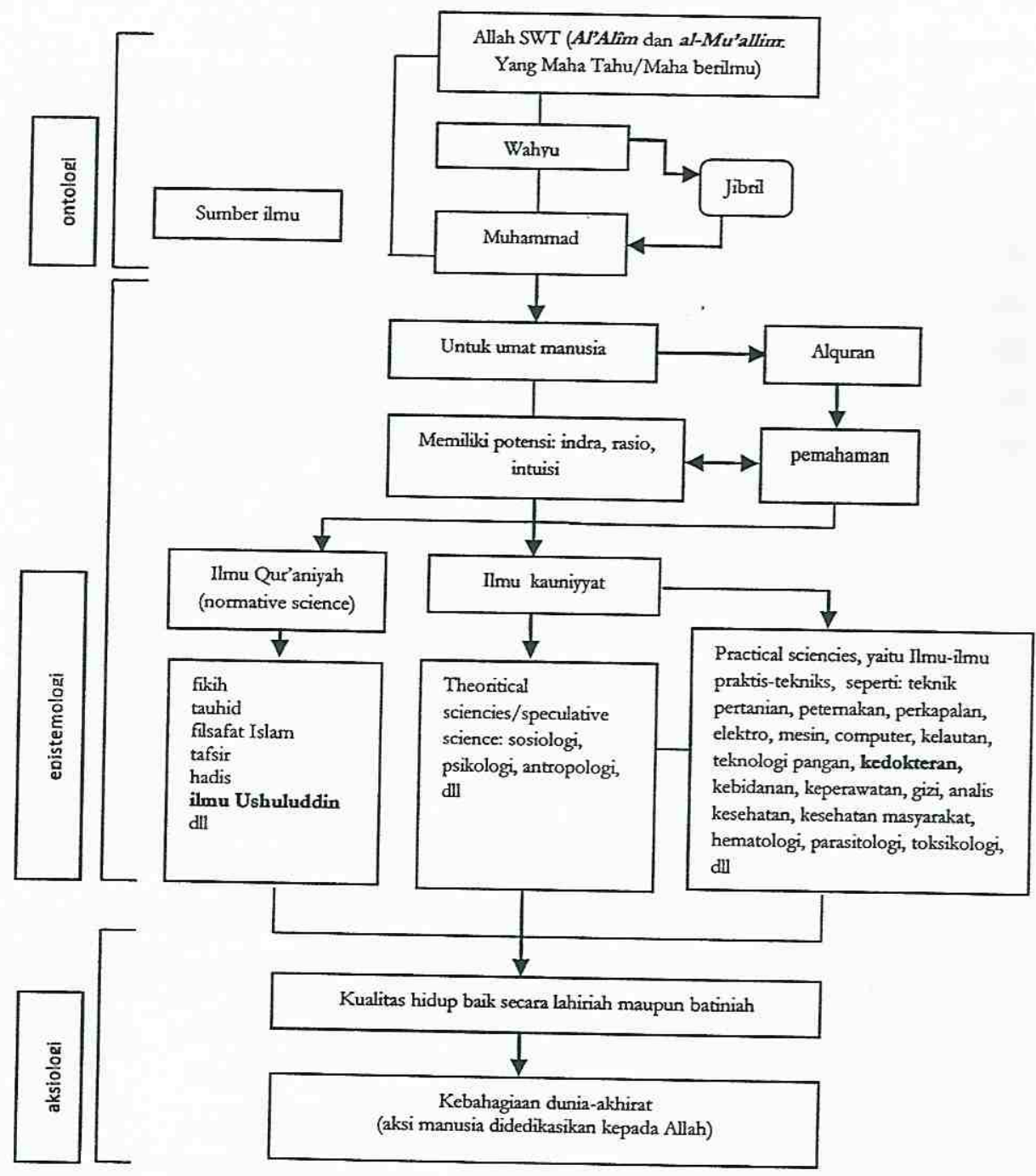




\section{Keterangan:}

1. Ontologi adalah cabang filsafat yang membahas tentang ada sebagai yang ada dalam arti seumum-umumnya. Jika sesuatu diputuskan 'ada', sesuatu itu bisa dibahas lebih lanjut. jika sesuatu diputuskan 'tidak ada' berarti selesai, dalam arti tidak ada pembahasan.

2. Epistemologi adalah cabang filsafat yang membahas tentang prosedur bagaimana pengetahuan itu diperoleh.

3. Aksiologi adalah cabang filsafat yang membahas tentang manfaat dari suatu ilmu Madzkur, 1979 : 20, 1, 26).

4. Atas dasar perkembangan llmu lebih lanjut telah melahirkan ilmu yang sumbernya merupakan kolaborasi antara ilmuilmu teoritis dengan ilmu teknis-praktis, seperti: sosiologi terapan, psikologi terapan, kesehatan terpadu (medical care dan spiritual care), bahkan betkembang pula kolaborasi antara seni dan ilmu, seperti: seni bangunan, seni tata ruang, seni tata kota, tata lampu, tata rias, dst.

Dari bagan di atas dapat dipahami pula bahwa ilmu itu hanya satu, bukan sekedar unity of sciencies, berasal dari Yang Maha Satu (The One), negasi dari terma ilmu agama dan ilmu umum, dan kebermacaman ilmu hanyalah spesifikasi terhadapnya karena kegiatan pengembangan ilmu yang ditentukan oleh objek, ruang lingkup, tujuan, metodologi, dan metodenya secara berkesinambungan.

\section{Penutup}

Mengakhiri tulisan ini di resume sebagai berikut:

1. Allah adalah Pencipta alam seisinya, satu diantaranya adalah manusia

2. Manusia beriman kepada Allah dengan segala manifestasinya, satu diantaranya beriman kepada Alquran. 
3. Alquran memerintahkan kepada orang yang beriman kepadanya agar membacanya. Realisasi membaca dalam bingkai akademik antara lain merenung, meneliti, eksperimentasi, konseptualisasi, teorisasi, dan pembentukan ilmu.

4. Hasil kegiatan membaca adalah memperoleh sesuatu: konsep, ide, variabel. Hubungan dasar dua atau lebih konsep dan variabel adalah teori. Hubungan sistematis-rasional sejumlah teori serumpun menghasilkan ilmu.

5. Alquran adalah sumber petunjuk bagi manusia, satu diantaranya sebagai sumber ilmu. Dengan demikian tidak ada sekat ilmu agama dan ilmu umum, melainkan ilmu itu satu yaitu berasal dari Allah ('allamabul bayân, 'allamal insâna mâ lam ya'lam) antara lain secara legal disalurkan melalui pewahyuan, selanjutnya dikodifikasikan dalam bentuk mushaf Alquran. Pembidangan dan konsorsium ilmu berakar dari ilmu Allah yang satu ini.

6. Ilmu Ushuluddin dan ilmu kedokteran, masing-masingnya, merupakan satu diantara sampel hasil pembidangan dari ilmu Islam, atau dengan kata lain, ilmu Ushuluddin adalah bagian dari Imu Islam melalui jalur ilmu qur'aniyyah, sedang ilmu kedokteran bagian dari ilmu Islam melalui jalur ilmu kauniyyah. Keduanya secara umum, demikian juga lain-lain ilmu, merupakan hasil dari kegiatan konseptualisasi, teorisasi, dan saintifikasi intelek ilmuwan/pemikir yang bertujuan untuk memperoleh kebahagiaan dunia-akhirat, bagi dirinya maupun orang banyak.

7. Ilmu Ushuluddin dan ilmu Kedokteran dengan demikian adalah bagian integtal dari Ilmu Islam itu sendiri. 


\section{DAFTAR PUSTAKA}

Al-Qur'an al-Karim.

'Abd al-Baqi, Ahmad Fuad, [t.th.], al-Mu'jam al-Mufabras li Alfaz alQur'ân al-Karim. Indonesia: Maktabah Dahlan.

Goode, William J\&Hatt, Paul K., 1952, Methods in Social Research, New York: Mac Grow Hill Book.

A Kadir, Muslim, 2003, Ilmu Islam Terapan. Yogyakarta: Pustaka Pelajar.

Kraar, Louis, "The New Power of Asia" dalam Reader Digest (edisi Asia), Vol.I.52. No.309, Desember 1988.

Kemeney, John G, 1981, A Philoshopher Looks at Science. New York: Van Nostrand Reinhold.

Mazkur, Ibrahim, 1979, al-Mu'jam al-Falsafi. Qahirah: Jamhuriyyah Mishr al-'Arabiyyah.

Nasution, Harun, 1973, Falsafat dan Mistisisme Dalam Islam, Jakarta: Bulan Bintang.

Noeng Muhadjir, 1996, Metologi Penelitian Kualitatif, Yogyakarta: Rake Sarasin.

Popper, Karl R., 1972, Conjectures and Refutations, London: Routledge and Kegan Paul.

Rowman and Littlefield.

Quraish Shihab, 1992, Membumikan Al-Quran, Jakarta: Mizan.

Rahmat, Jalaluddin, 1988, Islam Alternatif. Bandung: Mizan.

Runes, Dagobert D, 1976, Dictionary of Pbilosopby. Totowa-New Jersey: Little field \& Adams Co.

Russel, Bettrand, 1979, Human Knowledge, Its Scope and Limits. Oxford: Oxford Press. 
------, 1985, The Impact of Scienceon Sociaty, London: Unwin Paperbacks.

Van Laer, P.Henry, 1962, Pbilosopby of Science, I, Pittburg: Duquesne University Press.

http://azmiradhiya.blogspot.com/2010/01/khasiat-madu-menurut -al-quran.html

http://talazoft.blog.usu.ac.id/2009/08/12/lebah-dan-madu-dalamalquran

http://khasiatmaduhabbatussauda.blogspot.com/2009/01/madudalam-timbangan-medis-dan-al-quran.html

http://obatradisional.info/manfaat-madu-untuk-kesehatan-dankecantikan.html

http://majalahkesehatan.com/7-manfaat-madu-untuk-kesehatan/ http://www.syafir.com/2011/12/25/manfaat-madu-untuk-

kesehatan

http://obatsakit2011.blogspot.com/2011/07/madu-dalam-alquran.html

http://suplirahim.multiply.com/journal/item/192/LEBAH_ MADU_UBAT_MUJARAB_MENGIKUT_SUNNAH_NA BI_SAW?\&show_interstitial $=1 \& u=\% 2$ Fjournal $\% 2$ Fitem 